\title{
KOCKANJE I KAZNENO-PRAVNA ZAŠTITA MLADIH U BOSNI I HERCEGOVINI
}

\author{
UDK: $1.343 .56(497.6)$ \\ 174.6-053.6 \\ DOI: $10.31141 /$ zrpfs.2021.58.142.1261 \\ Pregledni rad \\ Primljeno: 01. 12. 2020.
}

\begin{abstract}
Kockanje kao društvena devijacija postaje sve aktuelniji problem u današnjem svijetu konzumerizma i poremećenih društvenih vrijednosti. Kao društvena devijacija svojom masovnošču prijeti da preraste u vodeću ovisnost koja bi vodila u razne oblike kažnjivog ponašanja. Takva prijetnja posebno je izražena za mladi naraštaj koji lako može postati ovisan o ovoj devijaciji i usljed toga biti izložen raznim oblicima prestupničkog ponašanja. U ovom radu, autori su elaborirali kazneno-pravnu zaštitu mladih od kockanja sa cjelovitom interpretacijom svih njenih oblika, te ukazali na određene nedostatke u legislativnim aspektima te zaštite i neujednačenost zakonske regulative koja se odnosi na ovaj oblik asocijalnog ponašanja mladih, kao i probleme u efikasnosti provođenja zakonskih odredbi koje tretiraju zaštitu mladih od kockanja u Bosni i Hercegovini, uz prezentovanje odgovarajućih prijedloga de lege ferenda usmjerenih na poboljšanje kazneno-pravne zaštite mladih u svim njenim oblicima i modalitetima.
\end{abstract}

Ključne riječi: krivično-pravna zaštita, prekršajno-pravna zaštita, kockanje, ovisnost

\section{UVODNO O KOCKANJU}

U novije vrijeme, zbog svoje ekspanzije velikih razmjera pogotovo među mlađim naraštajem i svog razornog i negativnog uticaja na mladu populaciju, nijedna sociopatološka pojava nije toliko dobila na aktuelnosti kao što je to slučaj sa kockanjem. Kockanje predstavlja jedan od vidova socijalne patologije u kome učestvuju ogromne mase ljudi iz raznih društvenih slojeva, te neuporedivo više i masovnije nego u drugim vidovima sociopatološkog ponašanja (alkoholizam,

1 Docent za krivično-pravnu naučnu oblast na Univerzitetu u Zenici. Zaposlen u Ministarstvu unutrašnjih poslova Zeničko-dobojskog kantona, suad.orlic@gmail.com

2 Docent za krivično-pravnu naučnu oblast na Pravnom fakultetu Univerziteta u Travniku. Zaposlen u Državnoj agenciji za istrage i zaštitu, Bosna i Hercegovina, karovic.s@hotmail.com 
prostitucija). Ono se sastoji u igri ${ }^{3}$ za novac ili druge vrijednosti, na osnovu određenih pravila, u formi hazarderstva, klađenja i sl. Osnovni elementi igre preobraženi u kocku su: alea, sreća i neizvjesnost, te se prema tim elementima usmjerava ponašanje osobe obuzeto željom da se nešto dobije ni za šta ili mnogo za malo, a što zavisi od sticaja slučajnih okolnosti (Milutinović, 1979: 346).

Kocka je igra preobražena u strast, opsesiju i dominantan motiv ponašanja, odnosno igra koja se preobražava u socijalnu izopačenost (Milosavljević, 1986: 123). Kockanje kao igra uključuje ulaganje novca radi dobitka uz prisutnost rizika i nade da će se vratiti uloženo ili dobiti više od toga. Kad se više ne može kontrolisati igrač ulazi u ovisnost usljed koje će sigurno uči u zonu kažnjivosti i prestupništva, te štetiti i sebi i drugima.

Za kockanje je karakteristično da se radi o igri, odnosno vrsti aktivnosti u kojoj igrači dobrovoljno učestvuju u međusobnom prenošenju (gubljenju i dobijanju) novca ili neke druge stvari od vrijednosti, a koja zavisi od neophodnog događaja na koji igrači ne mogu da utiču (Špadijer-Džinić, 1988). Danas je sve veća dostupnost igara na sreću, pri čemu je masovnost i prihvatanje kockanja kao legalnog obrta rezultiralo sve češčim patološkim kockanjem, odnosno ovisnošču o kocki, i od 1980 godine uvršteno je u Međunarodnu klasifikaciju bolesti (Klarić, 2014: 74).

Kockanje prouzrokuje brojne posljedice kod (patoloških) kockara (lica ovisnih o kockanju) počev od zdravstvenih koje se odražavaju na psihičko i tjelesno zdravlje kockara, ali i drugih članova porodice, pa preko porodičnih koje se odnose na funkcionisanje porodice i uzrokovanje njene disfunkcionalnosti, te socijalne $\mathrm{i}$ profesionalne posljedice u smislu negativnog uticaja patološkog kockanja na radne i profesionalne sposobnosti kockara. Posljedice kockanja kao socijalno patološke pojave su izuzetno destruktivne i dugoročne ne samo za lice koje neposredno učestvuje u ovim aktivnostima već i za članove njegove porodice. Usljed kockanja dolazi do degradacije ličnosti, kao i degradacije porodice, jer se na kockanje troše velika novčana sredstva, usljed čega ono u velikoj mjeri ugrožava i porodični budžet što posljedično tome dovodi i do osiromašenja porodice. Za kockare vrijedi jedna Italijanska poslovica koja glasi da „Nije izgubio onaj ko je izgubio, već onaj ko hoće izgubljeno vratiti“. U vezi sa tom poslovicom, mnogo više se gubi u pokušaju vraćanja izgubljenog (novca), pri čemu se u tom pokušaju koriste sva sredstva od kojih se najčešče poseže za činjenjem krivičnih djela, tako da se može reći da se u kockanju često ukradenim pokušava doći do vraćanja izgubljenog, što samo predstavlja dublje poniranje u svijet izgubljenih osoba.

Kockanje kao igra ima za cilj prije svega zabavu, kao i zadovoljenje psiholoških i socijalnih potreba i tada ono nema devijantni karakter. Ovde spadaju različiti oblici igara na sreću od kockarskih mašina, ruleta, pa sve do sportske kladionice, odnosno sportske prognoze. To su legalizovani oblici klađenja, koji donose i ekonomsku dobit za državu u vidu poreza od igara na sreću, i s tog aspekta ne predstavljaju devijantno ponašanje. Međutim s moralnog i religijskog aspekta, takva ponašanja su devijantna i u suprotnosti sa moralnim normama i principima religije, a takodje su devijantna i iz razloga što su put, odnosno uvod u prestupničke oblike ponašanja. 
Ovisnost o kockanju je uglavnom vezana za muškarce, ${ }^{4}$ jer je kockanje u raznim oblicima manifestacija muške potrebe za neizvjesnošću i koketiranjem s opasnošću. Međutim, u novije vrijeme, sve više lica ženskog spola povremeno ili kontinuirano učestvuje u određenim oblicima kockanja, tako da ova pošast savremenog doba koja zavređuje dužnu pažnju naučne - stručne ali i opšte javnosti, nije svojstvena isključivo samo za muškarce. Ovisnici od kockanja nisu samo tipovi koji su opsjednuti kockanjem i kladionicama, nego i mnogi od „hrabrih“ poduzetnika i berzanskih špekulanata (Munjiza, 2017: 385). Kockanje kao društvenja devijacija ima određene karakteristike od kojih je naročito značajno istači činjenicu da se u procesu kockanja ne stvaraju nove materijalne vrijednosti već se samo ista količina materijalnih dobara prenose od učesnika do učesnika, kao i to da se sekundarna posljedica kockanja javlja nakon završene igre kada kockar pokušava da nadoknadi materijalna sredstva koja je izgubio u procesu kockanja (Šarić, 2008. 1609, pri čemu je način nadoknade tih sredstava uglavnom prožet kriminalnim radnjama. Kockanje je, dakle, usko povezano i sa kriminalitetom. Naime, da bi došli do velikih novčanih sredstava kockari najčešće vrše imovinska krivična djela poput krađa, ucjena i prevara. Praktično je nemoguće kockanje kao socijalno patološku pojavu promatrati izolavano, bez njene povezanosti i uslovljenosti sa raznim oblicima kriminaliteta. Iskustva iz prakse ukazuju da je kockanje veoma često put u kriminal. U većini zemalja u svijetu kockanje u vidu zanimanja i profesionalne djelatnosti predviđeno je kao krivično djelo. ${ }^{5}$

Kockanje se ispoljava u raznim vidovima, počev od neorganiziranih oblika (klađenje, lutrija, obični rulet, kockarski automat, igranje u klubovima itd.), pa do organizirane kocke, koja danas uzima sve više maha u svijetu, jer se ono odvija u privatnim stanovima i kućama zbog čega se jako teško otkriva (Mirić, 2014: 252). U nekim zemljama, organizirana kocka se, bez obzira na to što se provodi u skladu sa zakonom odnosne države, nalazi pod kontrolom kriminalnih podzemlja.

Kockanje nije prisutno u stručnoj literaturi u mjeri u kojoj bi to stereotip viđenja ove devijacije nalagao. Različita objašnjenja pojave, uglavnom sociološka i psihološka, nisu saglasna u viđenju problema, pa je teško na osnovu toga razjasniti etiologiju ove devijacije (Nikolić, 2006: 100).

4 Povijesno je odnos muškarci žene 2:1, tako da su približno dvije trećine osoba s patološkim kockanjem muškarci, a jedna trećina su žene (Šarić, 2008: 161).

5 Kockanje kao kolektivno krivično djelo u vidu zanata postoji onda kada učinitelj nastoji da ponavljanjem nekog krivičnog djela sebi obezbjedi stalni ili dodatni izvor prihoda, tj. da ponavljanjem djela ostvaruje imovinsku korist. Kockanje, kao kolektivno krivično djelo u vidu zanata - kao jedan od oblika prividnog realnog sticaja, postojalo je u krivičnom zakonodavstvu bivše Jugoslavije, te poslijeratno i u Bosni i Hercegovini, s tim da nije postojalo u svim krivičnim zakonodavstvima u Bosni i Hercegovini, već samo u krivičnom zakonodavstvu entiteta Republika Srpska (čl.216.KZ RS, Službeni glasnik RS, br.3/96). U ovom i ranijem krivičnom zakonodavstvu korištena je formulacija „,ko se kocka u vidu zanata“ da bi izmjenama krivičnog zakonodavstva došlo do dekriminalizacije ovog djela, odnosno brisanja odredbe koja se odnosi na bavljenje kockanjem u vidu zanata. (Tomić, 2007a: 159). 
Danas postoje brojne vrste kockara, ${ }^{6}$ od kojih su, pored patoloških kockara, sociopatološki interesantni i antisocijalni i profesionalni kockari. Antisocijalni kockari su tipovi kockara koji se angažuju u kriminalnim aktivnostima i prevarama. Naime, kod takvih kockara kockanje predstavlja metod da ukradu novac (mogu da koriste označene kocke, obilježene karte, i „dojave“ sportskih događaja), te se razlikuju od patoloških kockara jer su spremni na zločin da vrate dug i mogu da imaju psihijatrijsku dijagnozu - antisocijalni poremećaj ličnosti. Profesionalni kockari su kockari kojima je kockanje primarni izvor prihoda i kod kojih ,zbog preokupiranosti kockanjem, postoji veliki rizik od razvijanja simptoma ovisnosti od kockanja. Radi se o kockarima koji rijetko gube kontrolu prilikom kockanja i kockaju metodično i planirano, te održavaju disciplinu i mogu da se uzdrže od impulsivnog kockanja, kao i da prihvataju finansijske gubitke bez potrebe da jure da ih povrate. (Mladenović, Lažetić, 2018: 59).

Danas su igre na sreću u svijetu i kod nas veoma raširene, pri čemu kockanje predstavlja posebnu opasnost za mlade. Postoje različiti oblici ili modaliteti kockanja koji su dostupni mladima, tako da postoji realna opasnost ili rizik da će mlada osoba bez adekvatnog nadzora roditelja ili staratelja, najčešće iz radoznalosti, početi se povremeno ili kontinuirano kockati, te ignorisati i zanemarivati društveno korisne aktivnosti. Postavlja se krucijalno pitanje kako pronaći efikasne i adekvatne preventivno - zaštitne mehanizme u odnosu na mlade kao specifičnu starosonu kategoriju i blagovremenim djelovanjem prepoznati i identifikovati rizična ponašanja, te poduzeti odgovarajuće aktivnosti na sprečavanju ulaska mladih u začarani i destruktivni svijet kocke. U tom smislu, potrebno je pored oficijelnih institucionalnih kapaciteta, resursa i mogućnosti u preventivni proces uključiti i sve druge vaninstitucionalne subjekte i pojedince kao autoritete koji svojim djelovanjem mogu dati značajan doprinos na planu prevencije (nevladin sektor, religijske zajednice, mediji, sportski kolektivi i dr.). Na planu prevencije kockanja kod mladih, prvorazrednu ulogu ima porodica, ali i škola s obzirom da roditelji odnosno članovi porodice kao i nastavno osoblje mogu uticati na razvijanje svijesti kod mladih osoba o štetnosti kockanja kao sociopatološke pojave, sa posebnim akcentom na destruktivne i dugoročne posljedice. Također, blagovremeno prepoznavanje i identifikacija rizičnih ponašanja koja ukazuju da je mlada osoba počela sa kockanjem i odgovarajuća (re)akcija roditelja, članova porodice, nastavnog osoblja i drugih pojedinaca kao autoriteta nameće se kao imperativ na planu preventivnog djelovanja i sprečavanja negativnih posljedica. Naime, danas je u tu pojavu uvučena armija mladih ljudi, prvenstveno muškog spola, koji provode vrijeme, odnosno dane i sate u raznim kladionicama, igraonicama i sličnim objektima koji su široko rasprostranjeni, posebno u velikim gradovima. Međutim, i u manje naseljenim mjestima (sela, naselja, kvartovi i dr.) egzistiraju kladionice s obzirom na mogućnost enormne zarade odnosno sticanja profita. Kockanje u raznim vidovima, koje se, po pravilu, zamišlja kao igra, često postaje strast usljed čega se zapuštaju obaveze i

6 Pored patoloških, antisocijalnih i profesionalnih kockara postoje i rekreativni kockari, svakodnevni (ozbiljni) kockari, problematični kockari, kockari koji „čeznu“ za uzbuđenjem, kockari koji bježe od problema (simptomatski kockari) itd (vidi, Mladenović, Lažetić, 2018: 57-63). 
usvajaju obrasci parazitskog vladanja, jer se stvara utisak da je moguće bez rada, napora i znanja osigurati lagodan život. Za kockanje kao oblik asocijalnog vladanja bitna je činjenica da može dovesti do deformacija u formiranju životne filozofije mladih, a može biti i uzrok sitnih krađa i prevara u kući, školi i na radnom mjestu (Skakavac, 2014: 111). Kockanje kao socipatološka pojava prevazilazi nacionalne geografske granice, tako da ni jedna država ili društvo nisu imuni na različite oblike kockanja, s obzirom da se ne radi o pravnom i društvenom fenomenu ili realitetu novijeg datuma već njegovu pojavu odnosno porijeklo nalazimo davno u prošlosti kao vjernog pratioca društva odnosno čovjeka sve do danas. Prisutnost kockanja na određenom geografskom području zavisi od više pretpostavki ali možemo konstatovati da je kockanje pronašlo izuzetno ,plodno tlo“ u državama koje se nalaze u procesu tranzicije kao što je Bosna i Hercegovina ali i države iz okruženja i regije. Kockanje se nerijetko promatra kao posljednja nada za mogućnost rješavanja problema finansijske prirode s obzirom na neizvjesnu i tešku ekonomsku situaciju. Međutim, kockanje po svojoj destruktivnoj prirodi i posljedicama, ni u kojem slučaju ne može biti izvor prihoda ili zarade već suprotno, direktan put u finansijski kolaps ne samo pojedinca (kockara) već i njegove cjelokupne porodice koja trpi štetne posljedice. S druge strane, neophodno je naglasiti da je kockanje prisutno i u demokratski uređenim i ekonomski razvijenim evropskim državama.

\section{KAZNENO-PRAVNA ZAŠTITA MLADIH OD KOCKANJA}

U Bosni i Hercegovini, kockanje, kao asocijalno ponašanje, odnosno sociopatološka pojava, propisano je u krivičnom i prekršajnom zakonodavstvu. Drugim rječima, u Bosni i Hercegovini kockanje se inkriminira i kao krivično djelo i kao prekršaj. Prilikom komparativne analize odredbi zakona koje se odnose na kockanje, potrebno je naglasiti veoma kompleksnu ustavnopravnu strukturu države Bosne i Hercegovine koja određuje i determinira vršenje sudske, zakonodavne i izvršne vlasti na svim nivoima (državni nivo, entiteti - Federacija Bosne i Hercegovine, Republika Srpska i Distrikt Brčko). Krivične inkriminacije koje su povezane sa kockanjem nisu propisane, odnosno različito su propisane u krivičnim zakonodavstvima u Bosni i Hercegovini. Naime, s jedne strane, kockanje kao krivično djelo nije propisano u svim krivičnim zakonima u Bosni i Hercegovini, tako da su krivična djela pod nazivom ,kockanje“ i ,organizovanje nedozvoljenih igara na sreću“ propisani samo u krivičnom zakonodavstvu entiteta Republika Srpska. S druge strane, kvalifikatorna okolnost koja se odnosi na odavanje asocijalnom ponašanju mladih, uključujući i kockanje, kod krivične inkriminacije ,Zapuštanje ili zlostavljanje djeteta ili maloljetnika“ propisana je u oba entitetska i krivičnom zakonodavstvu Brčko distrikta BiH. Kao prekršaj, kockanje je i jednako i dvojako propisano u prekršajnom zakonodavstvu u Bosni i Hercegovini. Jednako propisivanje kockanja kao prekršajnog djela podrazumjeva njegovu propisanost u oba entitetska 
i prekršajnom zakonodavstvu Brčko distrikta $\mathrm{BiH}^{7}{ }^{7}$ Dvojaka propisanost kockanja podrazumjeva da je kockanje propisano kao prekršaj prema dva zakona, odnosno, propisano je kao prekršaj protiv javnog reda i mira prema Zakonima o javnom redu i miru ${ }^{8}$ i kao prekršaj prema Zakonu o igrama na sreću, kao lex specialis, koji sveobuhvatno reguliše igre na sreću u koje se ubrajaju i kockanje i klađenje. U vezi navedenog, polazeci od propisanosti kockanja kao krivičnog i prekršajnog djela, možemo govoriti o dva aspekta kazneno-pravne zaštite mladih od kockanja u Bosni i Hercegovini: krivično-pravnoj i prekršajno-pravnoj zaštiti mladih od kockanja.

\section{KRIVIČNO-PRAVNA ZAŠTITA MLADIH OD KOCKANJA}

Analizom odredbi krivičnih zakona na sva četiri nivoa, evidentno je da kockanje kao krivično djelo nije propisano u svim krivičnim zakonima u Bosni i Hercegovini. Naime, u KZ entiteta Federacija BiH i Brčko distriktu BiH kockanje nije propisano kao krivično djelo, dok su u krivičnom zakonodavstvu entiteta Republika Srpska propisane dvije inkriminacije koje se odnose na ovu sociopatološku pojavu. Naime, propisano je krivično djelo „organizovanje nedozvoljenih igara na sreću“, u okviru grupe krivičnih djela protiv imovine, iz člana 231. KZ RS, i krivično djelo „kockanje“, u okviru grupe krivičnih djela protiv javnog reda i mira, iz člana 368. KZ RS ${ }^{9}$, čime se pruža krivično-pravna zaštita lica od ovog vida sociopatološkog ponašanja. Za oba krivična djela, uz propisane kazne (novčana i/ili kazna zatvora), zakonodavac je predvidjeo i obavezno izricanje mjere bezbjednosti oduzimanje predmeta, što je u funkciji sprečavanja daljeg bavljenja ovom djelatnošću. U vezi navedenog, s obzirom da je kockanje kao prekršaj protiv javnog reda i mira predviđen u prekršajnom zakonodavstvu oba entiteta u Bosni i Hercegovini, može se reći da je u kaznenom (krivičnom i prekršajnom) zakonodavstvu entiteta Republika Srpska kockanje, kao sociopatološka pojava, propisano, odnosno predviđeno i kao krivična inkriminacija i kao prekršaj (iz Zakona o javnom redu i miru i Zakona o igrama na sreću kao lex specialis), dok je u kaznenom zakonodavstvu entiteta Federacija Bosne i Hercegovine propisano samo kao prekršaj (iz oba navedena zakona). Kod krivične inkriminacije kockanje u članu 368, stav. 2. KZ RS zakonodavac je propisao kažnjavanje za radnju omogućavanja za nagradu kockanja svim licima putem stavljanja na raspolaganje prostorije radi kockanja ili omogućavanja kockanja na drugi način, što bi u širem smislu obuhvatalo i maloljetna lica. Ipak, nedostatak kod ovog krivičnog djela je u tome što nije propisana eksplicitna odredba o kažnjavanju lica za radnju navođenja djeteta, odnosno maloljetnika na kockanje koja bi predstavljala kvalifikatornu okolnost s obzirom na starosnu dob pasivnog

Kockanje kao prekršajno djelo je propisano u svim prekršajnim zakonodavstvima. Međutim, u okviru te propisanosti postoji razlika između zakonodavstava u pogledu propisanosti ili nepropisanosti radnje navođenja, odnosno podstrekavanja na kockanje ili omogućavanje kockanja, kao obilježja bića prekršajnog djela, kao i razlika u pogledu propisanosti visine novčane kazne, za počinjeni prekršaj.

8 Zakoni o javnom redu i miru Republike Srpske i Zakon o javnom redu i miru Brčko Distriktu BiH, te 10 kantonalnih Zakona o javnom redu i miru u Federaciji Bosner i Hercegovine.

9 Službeni Glasnik Republike Srpske, br.64/17 i 104/18 odluka US). 
subjekta i teži oblik djela, čime bi se pružila krivično-pravna zaštita djece, odnosno maloljetnika od radnji podstrekavanja, odnosno navođenja od strane punoljetnih lica na bavljenje ovim vidom sociopatološkog djelovanja. U vezi navedenog potrebne su izmene koje bi, s jedne strane, podrazumevale inkriminalizaciju, odnosno propisivanje ovog krivičnog dela u $\mathrm{KZ} \mathrm{FBiH}$, te, s druge strane, propisivanje u oba entitetska krivična zakonodavstva odredbe koja se odnosi na kvalifikatornu okolnost s obzirom na starosnu dob pasivnog subjekta, odnosno inkriminirajuću radnju navođenja maloletnika na kockanje. Ova izmena je potrebna iz razloga kako bi se prevashodno propisivanjem odredbe o kvalifikatornoj okolnosti koja se odnosi na radnju navođenja maloljetnika na kockanje, u oba entitetska krivična zakonodavstva, postigla bolja krivičnopravna zaštita maloletnika od kockanja i kako bi se takva zaštita maloletnika od ovog oblika ovisnosti odnosila na celi teritorij Bosne i Hercegovine (Orlić, Krštenić, Karović, 2019: 307).

Pored krivičnih djela „kockanje“ i „organizovanje nedozvoljenih igara na sreću" propisanih samo u KZ RS, bez odredbe o sankcionisanju radnje navođenja djeteta, odnosno maloljetnika na kockanje, značajno je istaći da se krivičnopravna zaštita maloljetnika od kockanja pruža u krivičnoj inkriminaciji, iz grupe krivičnih djela protiv braka i porodice, pod nazivom „Zapuštanje ili zlostavljanje djeteta ili maloljetnika“ iz člana 219 KZ FBiH i člana 216 KZ BDBiH, odnosno „Zapuštanje i zlostavljanje djeteta“ iz člana $187 \mathrm{KZ} \mathrm{RS.}{ }^{10} \mathrm{U}$ navedenoj inkriminaciji, u stavu 3

10 Ovakva inkriminacija sa drugačijim nazivom je propisana u krivičnom zakonu entiteta Republika Srpska u odnosu na Krivični zakon entiteta FBiH i KZ BD BiH. Radi se o inkriminaciji „Zapuštanje i zlostavljanje djeteta“ iz člana $187 \mathrm{KZ}$ RS. U krivično-pravnom smislu, u smislu deliktne sposobnosti ili nesposobnosti, dijete i maloljetnik se različito definišu, tako da se dijete smatra osobom koja je tempore criminis bila uzrasta do navršenih 14 godina, a maloljetnik osobom uzrasta od navršenih 14 do navršenih 18 godina. Specifično za krivično zakonodavstvo u Bosni i Hercegovini je to da pojam djeteta je različito definisan u entitetskim krivičnim zakonodavstvima i krivičnom zakonodavstvu Brčko distrikta, kao što je i pojam djeteta terminološki različito definisan i neusklađen u Krivičnom zakonu i Zakonu o maloljetnicima Federacije BiH i Brčko distrikta BiH. Naime, u krivičnom zakonodavstvu entiteta Republika Srpska pojam djeteta i maloljetnika su definisani Zakonom o maloljetnicima po kojem je pojam djeteta usklađen sa pojmom djeteta iz Konvencije UN o pravima djeteta, tako da se radi o osobi uzrasta do navršenih 18 godina. Za razliku od Republike Srpske, u Krivičnom zakonodavstvu entiteta Federacija BiH i Brčko distriktu BiH, pojam djeteta je definisan i u KZ i u odvojenom Zakonu o maloljetnicima, pri čemu je primjetna neusklađenost terminološkog određenja pojma djeteta u ova dva zakona. Naime, u KZ FBiH, u krivično-pravnom smislu, terminološki je odvojen pojam djeteta i maloljetnika tako da je dijete definisano kao lice koje je tempore criminis uzrasta do navršenih 14 godina, te maloljetnik kao lice uzrasta do navršenih 18 godina, dok u Zakonu o maloljetnicima termin ,dijete“ je definisan kao lice uzrasta do navršenih 18 godina, tako da u sebi sadrži i pojam, odnosno dob maloljetnika. Neophodno je otkloniti tu neusklađenost i dijete, kao pojam koji uključuje i dob maloljetnika, definisati onako kako je to definisano u Zakonu o maloljetnicima RS, pri čemu je razlikovanje između pojma dijete i maloljetnik potrebno u krivično-pravnom smislu, odnosno u smislu deliktne sposobnosti ili nesposobnosti, tako da se dijete u deliktnom smislu definiše kao lice koje tempore criminis nije navršilo 14 godina, te ne podliježe krivnji i nesposobno je za krivnju, dok se maloljetnici, kao lica koja su u vrijeme učinjenja krivičnog djela imala navršenih 14 i nenavršenih 18 godina, smatraju deliktno sposobnim i podliježu krivnji. Uslijed različitog naziva ovog krivičnog djela, i objekti krivičnopravne zaštite se različito odredjuju, tako da kod krivičnog djela „Zapuštanje ili zlostavljanje djeteta ili maloljetnika“" u KZ FBiH objekt krivično-pravne zaštite je dijete ili maloljetnik (vid. Tomić, 2007b: 136) što znači da je odvojeno definisan i da se pod pojam dijete ne uključuje i dob maloljetnika, dok kod ovog djela u KZ RS objekt krivično pravne zaštite je dijete, odnosno lice do 18 godina života, što pod pojmom dijete uključuje i dob maloljetnika (vid, Babić, Marković, 2018: 151). U krivično-pravnoj teoriji se koristi termin maloljetno lice za lice uzrasta do navršenih 18 godina, što uključuje i dobnu kategoriju djeteta, kao deliktno nesposobne osobe, do navršenih 14 i dobnu kategoriju maloljetnika (mladjeg i starijeg), kao deliktno sposobne opsobe, od navršenih 14 do navršenih 18 godina. 
propisan je kvalifikatorni, teži oblik ovog krivičnog djela koji se odnosi na nastupanje, usljed djela iz stava 1 i 2 navedenog člana, posljedice koja se ogleda u odavanju asocijalnom ponašanju, u koje ubrajamo i kockanje. Naime, ovo krivično djelo u osnovnom obliku, u stavu 1, propisuje zapuštanje djeteta grubim zanemarivanjem, od strane roditelja, usvojitelja, staratelja ili drugog lica, svoje dužnosti zbrinjavanja i vaspitanja djeteta ili maloljetnika (djeteta u KZ RS) o kojem je dužno da se stara, dok je u drugom, težem obliku, u stavu 2, propisana odredba koja sadrži više opciono propisanih kvalifikatornih radnji koje roditelji, usvojitelji ili staratelji čine prema djetetu i ogledaju se u zlostavljanju djeteta ili prinuđavanju na pretjerani rad ili rad koji ne odgovara uzrastu maloljetnog lica, ili na prosjačenje, ili na navođenje iz koristoljublja na vršenje drugih radnji koje su štetne za njegov razvoj.

Kod krivičnog djela „Zapuštanje ili zlostavljanje djeteta ili maloljetnika“ u članu 187.st.3. KZ FBiH propisan je kvalifikovani, teži oblik ovog djela, usljed kojeg je propisana strožija kazna u odnosu na osnovni oblik djela, i više kvalifikatornih okolnosti koje su alternativno postavljene tako da je za postojanje ovog težeg oblika, odnosno za primjenu ove kvalifikacije djela dovoljno da nastupi jedna od njih. Jedna od alternativno propisanih kvalifikatornih okolnosti, pored teškog tjelesnog povređivanja ili teškog narušenja zdravlja djeteta ili maloljetnika, odnosi se na odavanje djeteta ili maloljetnika prostituciji, alkoholu i drugim oblicima asocijalnog ponašanja, ${ }^{11}$ uključujući i kockanje, usljed učinjenja ovog djela iz prva dva stava ovog člana. Dakle, odavanje djeteta ili maloljetnika asocijalnom ponašanju, pa time i kockanju, javlja se kao posljedica počinjenog djela u osnovnom i težem obliku, odnosno kao posljedica grubog zanemarivanja odgoja djeteta ili maloljetnika ili njegovog izlaganja nekim od opciono propisanih kvalifikatornih radnji od strane roditelja, usvojitelja ili staratelja koje se odnose na zlostavljanje djeteta ili maloljetnika, njegovo prinuđavanje na pretjerani rad ili rad koji ne odgovara njegovom uzrastu, ili na prosjačenje ili na njegovo navođenje iz koristoljublja na vršenje drugih štetnih radnji za njegov razvoj. Time je zakonodavac kod ovog krivičnog djela propisivanjem, u članu 187.st.3. KZ FBiH, alternativno postavljene, odnosno određene kvalifikatorne okolnosti koja se odnosi na odavanje djeteta ili maloljetnika asocijalnom ponašanju, u koje ubrajamo i kockanje, kao posljedici izlaganja djeteta ili maloljetnika radnji grubog zanemarivanja odgoja iz osnovnog oblika djela, iz stava 1 ovog člana, i opciono propisanim kvalifikatornim radnjama počinjenim od strane roditelja, usvojitelja, staratelja ili drugog lica iz stava 2 ovog člana (usljed čega djelo dobija teži oblik kod kojeg je za učinitelja propisana strožija kazna od kazne propisane u osnovnom obliku), mladim licima, odnosno

11 U literaturi postoje različiti pristupi u interpretaciji šta se podrazumjeva pod ,,drugim oblicima asocijalnog ponašanja“ Pojedini autori (Babić, Marković, 2018: 152) daju šire, ekstenzivnije, objašnjenje pa pod pojmom drugih oblika asocijalnog ponašanja, uz sociopatološke oblike ponašanja koji se odnose na alkoholizam, narkomaniju, prostituciju, kockanje, skitnju i prosjačenje, podrazumjevaju i druge oblike asocijalnog ponašanja kao što su: stalno bježanje iz škole, izbjegavanje rada, kao i svako drugo ponašanje koje predstavlja značajnije odstupanje od usvojenih normi ponašanja u datom društvu. Ima i autora (Tomić, 2007b: 136) koji daju restriktivnije, uže objašnjenje, smatrajući., odnosno vezujući asocijalno ponašanje isključivo za najčešče sociopatološke pojave kao što su, uz navedenu prostituciju i alkohol, prosjačenje, kockanje, uživanje opojnih droga, odnosno narkomanija itd. 
djetetu ili maloljetniku osigurao (prema KZ FBiH i KZ BD BiH), odnosno pružio dodatnu (prema KZ RS) krivično-pravnu zaštitu od kockanja. ${ }^{12} \mathrm{U}$ odnosu na ovu kvalifikatornu okolnost, odnosno težu posljedicu djela, iz člana 219.st.3. KZ FBiH, koja se odnosi na odavanje asocijalnim oblicima ponašanja, uključujući i kockanju, kod učinitelja može postojati i umišljaj i nehat. U krivičnim zakonodavstvima u $\mathrm{BiH}$, prisutna je različita kaznena politika, odnosno propisana je različita visine kazne u odnosu na ovu kvalifikatornu okolnost. Naime, KZ FBiH i KZ BD BiH propisuju nižu mjeru kazne, odnosno niži posebni minimum i maksimum kazne za navedenu kvalifikatornu okolnost kod krivičnog djela „Zapuštanje ili zlostavljanje djeteta ili maloljetnika" tako da je za kvalifikatorni oblik djela iz čl.219.KZ FBiH i čl.216. KZ BD BiH koji se odnosi na odavanje djeteta ili maloljetnika asocijalnom ponašanju, odnosno kockanju, propisana kazna zatvora od tri mjeseca do pet godina, dok je za istu kvalifikatornu okolnost navedenog krivičnog djela iz člana 187.st.3. KZ RS propisana strožija kazna, odnosno viši posebni minimum i maksimum kazne unutar opšteg zakonskog kaznenog okvira, tako da je propisana kazna zatvora od 1 do 8 godina, čime se u krivičnom zakonodavstvu entiteta Republika Srpska mladim licima pruža jača krivično-pravna zaštita od kockanja u odnosu na drugo entitetsko krivično zakonodavstvo i krivično zakonodavstvo $\mathrm{BD} \mathrm{BiH}$. U cilju postizanja bolje i cjelovitije, te jače krivičnopravne zaštite mladih lica od kockanja, priedlog de lege ferenda je da se izvrši nekoliko izmjena u našem krivičnom zakonodavstvu. Prva izmjena se odnosi na to da se izvrši inkriminalizacija kockanja i u krivično zakonodavstvo FBiH i BD BiH kako bi se maloljetnicima pružila cjelovitija, odnosno krivično pravna zaštita na cijelom teritoriju $\mathrm{BiH}$, te da se u postojećoj inkriminaciji „kockanje“ u krivičnom zakonodavstvu Republike Srpske, uz uvođenje takve inkriminacije i u krivičnom zakonodavstvu $\mathrm{FBiH}$ i $\mathrm{BD} \mathrm{BiH}$, propise odredba o kažnjavanju lica za radnju navođenja djeteta, odnosno maloljetnika na kockanje koja bi predstavljala kvalifikatornu okolnost s obzirom na starosnu dob pasivnog subjekta i teži oblik djela, čime bi se pružila potpunija krivično-pravna zaštita djece, odnosno maloljetnika od ovog vida sociopatološkog djelovanja.

12 U KZ FBiH i BD BiH jedini vid krivično-pravne zaštite mladih lica od kockanja se osigurava, odnosno ostvaruje kroz propisivanje kvalifikatorne okolnosti kod krivičnog djela ,Zapuštanje ili zlostavljanje djeteta ili maloljetnika“ iz člana 219.st.3.KZ FBiH (Službene novine FBiH, br.75/17) i čl. 216. st.3. KZ BD BiH (Službene novine BD BiH, br.50/18), koja se odnosi na odavanje djeteta ili maloljetnika asocijalnim ponašanjima, uključujući i kockanje, kao posljedici grubog zanemarivanja odgoja djeteta ili maloljetnika (čl-219.st.1. KZ FBiH) ili njegovog izlaganja opciono propisanim kvalifikatornim radnjama (čl.219.st.2. KZ FBiH), dok se u KZ RS krivičnopravna zaštita mladih lica od kockanja, uz potrebu propisivanja odredbe o kaznjavanju za radnju navođenja maloljetnika na kockanje, ostvaruje kroz propisivanje dvije inkriminacije: „Kockanje“ iz člana 368 KZ RS i „Organizovanje nedozvoljenih igara na sreću“ iz člana 231. KZ RS (Službeni glasnik RS, 64/17 i 104/18), kao i kroz navedenu kvalifikatornu okolnost, tako da se propisivanjem navedene kvalifikatorne okolnosti kod inkriminacije ,Zapuštanje i zlostavljanje djeteta“ iz člana 187.st.3. KZ RS, uz propisivanje višeg posebnog minimuma i maksimuma kazne zatvora u odnosu na niži minimum i maksimum kazne zatvora propisan prema članu 219.st.3. KZ FBiH i čl.216. KZ BD BiH, mladim licima, uz navedene dvije krivične inkriminacije, pruža dodatna $\mathrm{i}$ jača krivično-pravna zaštita. To znači da se mladim licima u krivičnom zakonodavstvu entiteta RS pruža sveobuhvatnija i jača krivično-pravna zaštita mladih od kockanja, u odnosu na krivična-zakonodavstva u entitetu FBiH i Brčko distriktu BiH. 
Drugi prijedlog de lege ferenda odnosi se na to da se ujednači visina kazne, odnosno propiše jednak posebni minimum i maksimum kazne unutar opšteg kaznenog okvira za kvalifikatornu okolnost kod krivičnog djela „Zapuštanje ili zlostavljanje djeteta ili maloljetnika" koja se odnosi na odavanje asocijalnom ponašanju, odnosno kockanju, na način da se i u krivičnom zakonodavstvu $\mathrm{FBiH}$ i BD BiH propiše viši posebni minimum i maksimum kazne zatvora, odnosno da bude isti kao u KZ RS i iznosi od 1 do 8 godina, kako bi se time mladim licima pružila jača krivično-pravna zaštita od kockanja i drugih oblika asocijalnog ponašanja uzrokovanog radnjama grubog zanemarivanja odgoja djeteta ili maloljetnika iz stava 1.člana $219 \mathrm{KZ} \mathrm{FBiH}$ i opciono propisanim kvalifikatornim radnjama iz stava 2 istog člana, počinjenim od strane roditelja, usvojitelja, staratelja ili drugog lica.

\section{PREKRŠAJNO-PRAVNA ZAŠTITA MLADIH OD KOCKANJA}

Kockanje kao druga vrsta kaznenog djela, odnosno kao prekršajno djelo propisan je u oba entitetska i prekršajnom zakonodavstvu Brčko distrikta BiH. Pored toga, kockanje kao prekršaj propisan je dvojako. Naime, odredbe o kockanju kao prekršaju propisane su kako u Zakonu o javnom redu i miru, tako i u Zakonu o igrama na sreću kao lex specialis, koji sveobuhvatno reguliše igre na sreću u koje se ubrajaju i kockanje i klađenje.

Odredbe o kockanju kao prekršaju iz Zakona o javnom redu i miru propisane su u oba entitetska i prekršajnom zakonodavstvu Brčko distrikta BiH. Ovim odredbama propisana je opšta zakonska formulacija kockanja kao prekršaja prema Zakonu o javnom redu i miru. Naime, zakonska formulacija kockanja, kao prekršaja prema Zakonu o javnom redu i miru je sljedeća: „Ko se kocka (igra hazardnu igru) za novac ili drugu korist tako da igra izgubi društveno zabavni karakter, ili ko za tu svrhu ustupi prostorije, osim u slučaju kocke (igranja hazardne igre) koja se odvija u za to namjenjenim prostorijama koje su registrovane za tu vrstu djelatnosti, ili ko omogućava licu mlađem od 18 godina da se kocka ${ }^{13}$ (igra hazardnu igru ili se kladi) u objektima koji su namjenjeni za tu vrstu djelatnosti, kaznice se novčanom kaznom “. ${ }^{14} \mathrm{U}$ pogledu ove zakonske formulacije kockanja kao prekršaja prema Zakonu o javnom redu i miru potrebno je razjasniti šta se podrazumjeva pod kockanjem kao prekršajnim djelom, zatim, kada kockanje ima društvreno zabavni karakter, a kada ne, odnosno kada je kockanje prekršaj, a kada to prestaje da bude, te kada ustupanje prostorija radi kockanja, predstavlja prekršaj, odnosno jednu od prekršajnih radnji i obilježja bića prekršajnog djela, a kada to ne predstavlja prekršaj.

13 Ova odredba o kažnjavanju za radnju navođenja maloljetnika na kockanje ili omogućavanje istom kockanja je propisana samo u nekim prekršajnim zakonodavstvima. Tako npr. takva odredba nije propisana u Zakonu o JRM ZDK i Zakonu o JRM BD BiH, dok je propisana u Zakonu o JRM KS, ZJRM HNK, itd. U Zakonu o JRM entiteta RS propisana je odredba o kažnjavanju za radnju navođenja drugog na kockanje, uključujući i maloljetmo lice, ali nema eksplicitne propisanosti odredbe o kažnjavanju za radnju navođenja, isključivo, malojetnika na kockanje.

14 Posebno je izražena različita propisanost visine novčane kazne za počinjeni prekršaj kako između kantonalnih zakona, tako i u odnosu na prekršajno zakonodavstvo BD BiH i entiteta RS. 
Kockanje kao prekršaj predstavlja hazardnu igru sa isključivim ciljem da se postigne imovinska korist. Radi se o igri u kojoj učestvuje više lica (najmanje dva), a kojima se pruža mogućnost da na ovaj način pribave novac ili stvari od vrijednosti, pri čemu krajnji ishod ne zavisi od znanja ili sposobnosti učesnika u igri, već od nastupanja ili nenastupanja nekog unaprijed neizvjesnog događaja. Imovinska korist kao cilj i bitan elemenat bića ovog prekršaja uslovljena je mišljenjem da učesnik u ovakvoj igri očekuje da ostvari imovinsku korist koja će uvećati njegovu aktivu ili smanjiti pasivu (Tukar, 2018: 45).

Kockanje je veoma često igra ili zabava pa je veoma teško precizno utvrditi kada kockanje prerasta iz igre u asocijalno ponašanje (Karić, 2017: 117). Postojanje ili gubitak društveno zabavnog karaktera kocke kao igre je osnov za diferencijaciju kockanja kao prekršaja i nečeg što je patološko od kockanja koji nema takva obilježja kaznenog djela. Sve dok kockanje, odnosno radnje kockanja imaju društveno zabavni karakter takve radnje se ne smatraju prekršajem, tako da kockanje kao prekršaj postoji tek kada igra za novac ili drugu korist izgubi društveno zabavni karakter i postane obrazac ponašanja lica kao počinioca ovog prekršaja. ${ }^{15}$

Drugim rječima, osnovni kriterij za diferencijaciju „,normalnog“"16, od patološkog kockanja jeste percepcija shvatanja kocke, odnosno da li se ona shvata kao igra ili kao obrazac ponašanja. Naime, onog trenutka kada kocka kao igra prestane da to bude, odnosno izgubi društveno zabavni karakter i kada ona preraste u obrazac ponašanja pojedinca, ona postaje devijacija u odnosu na normalno i očekivano, pa izaziva otpor sredine i mijenja njen odnos prema takvom pojedincu (Nikolić, Joksić, 2011: 83).

Kada je u pitanje ustupanje prostorija radi kockanja, da bi ustupanje prostorija radi kockanja predstavljalo prekršaj potrebna je svijest i volja u pogledu toga da se prostorija ustupa radi kocke. To, zapravo, znači da onaj koji ustupa prostorije radi kockanja treba da postupa s umišljajem tako da zna i saglašava se, $\mathrm{u}$ formi htjenja ili pristajanja, da ustupa prostoriju radi kockanja. Ukoliko pak vlasnik prostorije nije znao da prostoriju ustupa radi kockanja, odnosno ukoliko se u ustupljenoj prostoriji kocka mimo volje i znanja lica koje je prostoriju ustupilo, odnosno mimo njegovog umišljaja, ovaj prekršaj ne postoji. Postojanje ove vrste prekršaja nije uslovljeno primanjem naknade, ali bi primljena naknada u svakom slučaju predstavljala protivpravnu imovinsku korist.

Za razliku od propisane zabrane umišljajnog ustupanja prostorija radi kockanja, Zakonodavac je s druge strane putem navedene zakonske formulacije legalizovao

15 U tom smislu, ukoliko npr. igranje karata, kugla ili slična radnja ima društveno zabavni karakter, odnosno vrše se radi razonode ili zabave, bilo češće bilo povremeno uz ulaganje simboličnih iznosa da bi igra bila interesantnija, igranje u piće koje se zajedno troši, ili u to da neko od učesnika nešto učini (skuha kafu, očisti obuću i sl), ovakve radnje ne smatraju se ovim prekršajem.

16 Pod normalnim kockanjem podrazumjevamo društveno prihvatljivo kockanje kod kojeg osoba koja normalno kocka i shvati kocku kao igru ili zabavu može da ograniči svoje gubitke i „zaustavi se dok još dobija“. Takva osoba koja kocka je više motivisana željom za razonodom - zabavom, a manje zadovoljenjima konfliktnih potreba. Patološko kockanje je bolest gdje se osoba ne može oduprijeti impulsima za kockanjem što dovodi do ozbiljnih zdravstvenih, porodičnih, socijalnih i profesionalnih posljedica (Mladenović, Lažetić, 2018: 40). 
kockanje, odnosno klađenje u prostorijama koje su registrovane za tu vrstu djelatnosti. Takav primjer su kladionice i drugi objekti u kojima se priređuju igre na sreću, uključujući i kockanje i klađenje, tako da kockanje i klađenje, te druge igre na sreću u tim i drugim objektima i prostorijama, ukoliko su registrovani za tu vrstu djelatnosti ne predstavlja prekršaj.

Prekršajno-pravna zaštita mladih od kockanja je regulisana dvojako, odnosno kako u Zakonu o javnom redu i miru, tako i u Zakonu o igrama na sreću kao lex specialis, koji sveobuhvatno reguliše igre na sreću u koje se ubrajaju i kockanje i klađenje.

Kockanje kao prekršaj je propisan u svim Zakonima o javnom redu i miru i zaštita mladih se prema ovom zakonu ostvaruje propisivanjem odredbe o odgovornosti svih lica, uključujući i maloljetnika za prekršajne radnje u kojima učestvuju, kao što je propisivanje odgovornosti za prekršajnu radnju kockanja kao jedne vrste ovisnosti. Radi se o neposrednoj odgovornosti maloljetnika za prekršajne radnje u kojima se oni pojavljuju kao učinioci, odnosno aktivni subjekti kaznenog, odnosno prekršajnog djela. ${ }^{17}$ Takođe, kazneno-pravna zaštita mladih (i krivičnopravna i prekršajno-pravna) se ostvaruje i propisivanjem odredbe o odgovornosti drugih lica za preduzimanje radnji (vezanih za kockanje) na štetu maloljetnika u kojima se oni pojavljuju kao pasivni subjekti. Radi se o odgovornosti drugih lica za radnju navođenja ili omogućavanja maloljetnicima da se izlože kockanju. Pored toga, kazneno-pravna (prekršajno-pravna, a izuzetno i krivično-pravna) zaštita mladih od ovisnosti se ostvaruje i propisivanjem odredbe o odgovornosti roditelja za počinjene prekršaje maloljetnika ukoliko su počinjeni prekršaji uzrokovani roditeljskim nečinjenjem, odnosno propuštanjem njihovog dužnog nadzora nad odgojem maloljetnika a takav nadzor su bili u mogućnosti da vrše.

Kada je u pitanju kockanje, kao prekršaj prema Zakonu o javnom redu i miru, postoje brojne razlike između prekršajnih zakonodavstava u Bosni i Hercegovini (kantonalnih Zakona o javnom redu i miru u entitetu FBiH i Zakona o JRM u entitetu RS i BD BiH) u pogledu odredbi koje se odnose na prekršajno-pravnu zaštitu mladih. Jedna od razlika se ogleda u tome što kod ovog vida prekršaja, prekršajna odredba iz Zakona o javnom redu i miru koja se odnosi na kažnjavanje lica za radnju navođenja maloljetnika na kockanje ${ }^{18}$ (u nekim zakonodavstvima se koriste termini "pozivanje“

17 Iako kazneno-pravna zaštita mladih podrazumjeva zaštitu mladih kao pasivnih subjekata kaznenih djela, i kod propisivanja odredbi o neposrednoj odgovornosti maloljetnika, odnosno njihovoj odgovornosti kao aktivnih subjekata ili počinilaca kaznenih djela koji se odnose na kockanje kao jednu od vrsta ovisnosti, čini se da je intencija zakonodavca da se kroz propisivanje ovakve odredbe postigne zaštita mladih od prestupničkog ponašanja kako u smislu specijalne, tako i u smislu generalne prevencije od ovog vida ovisnosti.

18 Navođenje ili pozivanje drugog na kocku predstavlja pridobijanje ili navođenje drugog lica, odnosno maloljetnika na kocku od strane lica koje ne učestvuje lično u samom kockanju. U praksi su npr. poznate situacije kada se neko lice bavi šibicarenjem (što je vrsta kockanja), a drugo lice koje navodno, odnosno tobože dobija veću količinu novca prilikom kockanja poziva i navodi druge na kockanje (Tukar, 2018: 44). 
ili „omogućavanje maloljetnicima“ da se kockaju) kao obilježja bića prekršajnog djela, nije propisana u svim, već samo u nekim prekršajnim zakonodavstvima. ${ }^{19}$

S tim u vezi, kao prijedlog de lege ferenda, trebalo bi u pogledu ove vrste prekršaja ujednačiti prekršajnu legislativu tako da u svim prekršajnim zakonodavstvima bude propisana prekršajna odredba koja se odnosi na kockanje uvođenjem i odredbe o kažnjavanju za radnju navođenja maloljetnika na kockanje od strane drugog (punoljetnog) lica kao kvalifikatorne okolnosti kod ovog prekršajnog djela s obzirom na starosnu dob pasivnog subjekta. Ratio legis ove izmjene, odnosno propisivanja kvalifikatorne okolnosti koja se odnosi na starosnu dob pasivnog subjekta, odnosno na to da se radnja navođenja, kao obilježje bića ovog prekršajnog djela, iz Zakona o javnom redu i miru, čini prema maloljetniku (navođenje maloljetnika na kockanje), usljed kojeg prekršajno djelo dobija teži oblik, kao i posljedično tome propisivanje većeg iznosa novčane kazne za lice koje je preduzelo radnju navođenja maloljetnika na kockanje, jeste u tome da se, kroz uvođenje ove kvalifikatorne okolnosti i propisivanja visokog iznosa novčane kazne za navođenje, odnosno podstrekavanje maloljetnika na kockanje, odvrate potencijalna odrasla lica od radnje navođenja maloljetnika na kockanje čime se postiže prekršajnopravna zaštita maloljetnika od ovog vida sociopatološkog ponašanja, pogotovo u današnje vrijeme kada kockanje poprima sve veće razmjere i u sve većoj mjeri postaje predmet interesovanja maloljetnika koji preko kockanja najčešće ulazi u svijet kriminala, kroz činjenje kaznenih djela usljed ovisnosti od kockanja (Orlić, Pehlić, Tufekčić, 2019: 199).

Pored navedenog, razlike u prekršajno-pravnoj zaštiti mladih od kockanja su prisutne i u pogledu odredbe o propisivanju odgovornosti roditelja za počinjeni prekršaj maloljetnika. Naime, u pogledu ovog vida prekršajno-pravne zaštite maloljetnika od kockanja koji se ostvaruje propisivanjem odgovornosti roditelja za kockanje maloljetnika kao oblik prekršajnog prestupništva mladih, postoje tri odredbe od kojih neke nisu propisane u svim prekršajnim zakonodavstvima. Prvom odredbom, koja je propisana u svim prekršajnim zakonodavstvima, prekršajnopravna zaštita mladih se ostvaruje propisivanjem odredbe o odgovornosti roditelja za počinjeni prekršaj maloljetnika uzrokovan roditeljskim nečinjenjem, odnosno propuštanjem dužnog nadzora nad odgojem maloljetnika ukoliko su takav nadzor nad odgojem bili u mogućnosti da vrše. ${ }^{20}$ Pored navedenog, postoji i odredba o odgovornosti roditelja za počinjeni prekršaj maloljetnika u noćnom periodu (obično od 23 do 06 h) uzrokovan roditeljskim nečinjenjem, kao i odredba o odgovornosti

19 Takva odredba o kažnjavanju za radnju navođenja maloljetnika za kockanje nije propisana u Zakonu o javnom redu i miru ZDK (vid, čl.3.tač.16. ZJRM ZDK - Službene novine ZDK, br. 12/16,), kao i u Zakonu o javnom redu i miru BD BiH ( čl. 15. ZJRM BD BiH - Službeni glasnik BD BiH, br. 14/10), dok je u Zakonu o javnom redu i miru RS propisana odredba o kažnjavanju za radnju navođenju lica, uključujući i maloljetna, bez propisanosti eksplicitne odredbe o kažnjavanju za radnju navođenja maloljetnih lica na kockanje (čl.13. ZJRM RS - Službeni glasnik RS, br. 11/15).

20 Utvrđivanje da li su roditelji bili u mogućnosti da vrše nadzor nad odgojem maloljetnika vrši se na osnovu procjene postojećih odgojnih kapaciteta u porodičnom okruženju. Nemogućnost roditelja da vrše dužni nadzor nad odgojem maloljetnika može se temeljiti na brojnim razlozima od kojih se naročito izdvajaju postojanje težeg oblika bolesti roditelja, razorenost porodice usljed smrti ili razvoda roditelja, ili pak postojanje kod roditelja raztličitih oblika socijalmne patologije, kao i poremećenost bračnih odnosa i sl. 
roditelja za podsticanje maloljetnika na vršenje prekršaja pri čemu ove odredbe nisu propisane u svim, već samo u nekim prekršajnim zakonodavstvima. ${ }^{21} \mathrm{U}$ vezi odredbe koja propisuje odgovornost roditelja za počinjeni prekršaj maloljetnika u noćnom periodu, uzrokovan roditeljskim nečinjenjem, postoje razlike u pogledu starosne dobi maloljetnika kao počinilaca prekršaja, odnosno razlike u pogledu odgovornosti roditelja s obzirom na starosnu dob maloljetnika kao počinilaca prekršaja, tako da je u nekim zakonodavstvima propisana odredba o odgovornosti roditelja za počinjeni prekršaj maloljetnika (i mladjih i starijih) kao počinilaca prekršaja kockanja u noćnom periodu, dok je u drugim zakonodavstvima propisana odredba o odgovornosti roditelja za počinjeni prekršaj isključivo mladjih maloljetnika, odnosno lica mladjih od 16 godina. $^{22}$ Shodno navedenom, prema pojedinim zakonodavstvima nije propisana odgovornost roditelja i za počinjeni prekršaj kockanja starijeg maloljetnika u noćnom periodu, tako da stariji maloljetnik sam snosi prekršajnu odgovornost za učešče u kockanju u noćnom periodu. Smatramo da prekršajnu odgovornost roditelja ne treba vezivati samo za počinjeni prekršaj mladjeg maloljetnika u noćnom periodu, već da tu odgovornost roditelja treba vezivati, odnosno proširiti i za počinjeni prekršaj starijeg maloljetnika. Razlog za ovakvo stajalište je u tome što i prema odredbama krivičnog zakona nema odvajanja mladjih i starijih maloljetnika u pogledu odgovornosti roditelja za vršenje dužnog nadzora nad njihovim odgojem, tako da je roditelj prema odredbama krivičnog zakona dužan da vrši dužni nadzor nad odgojem i ponašanjem maloljetnika, odnosno i mladjih i starijih maloljetnika. Shodno tome, u pogledu ove odredbe trebalo bi, u skladu sa odredbom propisanom prema Zakonu o javnom redu i miru entiteta Republika Srpska, propisati prekršajnu odgovornost roditelja za počinjeni prekršaj maloljetnika (i mladjeg i starijeg) u noćnom periodu uzrokovan roditeljskim nečinjenjem, ili pak u pogledu druge odredbe propisati ujednačenu odredbu o zajedničkoj odgovornosti, odnosno odgovornosti roditelja uporedo sa starijim maloljetnikom za počinjeni prekršaj kockanja starijeg maloljetnika u noćnom periodu. Dakle, prema ovom prijedlogu rješenja, radi se o propisivanju zajedničke odgovornosti roditelja sa starijim maloljetnikom za počinjeni prekršaj kockanja starijeg maloljetnika, i propisivanju u prvoj odredbi samostalne odgvornosti roditelja za počinjeni prekršaj kockanja mladjeg maloljetnika u noćnom periodu, s tim da je zakonodavac propisao strožiju kaznu, odnosno veći iznos novčane kazne za roditelje zbog počinjenog prekršaja kockanja maloljetnika u noćnom periodu, u odnosu na drugi period, uzrokovan roditeljskim nečinjenjem, što ima opravdanje, s obzirom na vrijeme počinjenja i veći stepen propusta roditelja u pogledu nadzora

21 Odredba o odgovornosti roditelja za počinjeni prekršaj maloljetnika u noćnom periodu (od 23 do $06 \mathrm{~h}$ ) nije propisana u prekršajnom zakonodavstvu ZDK (vid, čl.3.tač.26. ZJRM ZDK - Službene novine ZDK, br. 12/16, ) i BDBiH ( vid, čl. 34. ZJRM BD BiH - Službeni glasnik BD BiH, br. 14/10), a odredba o odgovornosti roditelja za podsticanje maloljetnika na kockanje je propisana u Zakonu o javnom redu i miru HNK (vid, čl.5.st.4.. tač.j, Službene novine HNK, br. 9/09).

22 Odredba o odgovornosti roditelja za prekršaj, u koji ubrajamo i kockanje, mladjeg maloljetnika u noćnom periodu propisana je u Zakonu o JRM SBK (čl.8.tač.5, Službene novine SBK, br,5/10) i Zakonu o JRM KS (čl.8, st.5, tač.l, Službene novine KS, br. 17/08), dok je u Zakonu o JRM entiteta RS propisana odredba o odgovornosti roditelja za prekršaj maloljetnika (i mladjih i starijih) u noćnom periodu (čl.27. st.2, Službeni glasnik RS, br. 11/15). 
nad ponašanjem, odnosno odgojem maloljetnika. Time je zakonodavac implicirao veći stepen odgojne zapuštenosti maloljetnika i veći stepen odgovornosti roditelja za propust u vršenju dužnog nadzora nad maloljetnikom u tom periodu, u odnosu na bilo koji drugi period u toku dana. U vezi navedenog za odgovornost roditelja, propisane u dvije različite prekršajne odredbe za počinjeni prekršaj maloljetnika u noćnom i drugom periodu, nastao kao rezultat propusta roditelja u vršenju njihovog dužnog nadzora nad odgojem maloljetnika ukoliko su takav odgoj bili u mogućnosti da vrše, kao prijedlog de lege ferenda, potrebno je izvršiti izmjene prekršajnog zakonodavstva na jedan od dva načina. Prema prvom načinu, potrebno je ujednačiti prekršajnu legislativu i u pogledu ovih odredbi, te s tim u vezi propisati ove odredbe kao ujednačene u svim prekršajnim zakonodavstvima, na način da se propiše odgovornost roditelja za počinjeni prekršaj kockanja maloljetnika (i mladjih i starijih) u noćnom i drugom periodu, uzrokovan roditeljskim nečinjenjem, u cilju postizanja većeg stepena odgovornosti roditelja u pogledu adekvatne supervizije ili kontrole nad ponašanjem maloljetnika i nadzora nad njihovim odgojem, te posljedično tome i postizanja jače prekršajno-pravne zaštite mladih od kockanja, uz propisanost većeg iznosa novčane kazne za roditelje po osnovu počinjenog prekršaja maloljetnika u noćnom periodu, u odnosu na drugi period, imajući u vidu vrijeme počinjenja navedenog prekršaja i veći stepen propusta roditelja u pogledu nadzora nad ponašanjem, odnosno odgojem maloljetnika. Prema drugom načinu prijedloga rješenja, potrebno je, uz zadržavanje neizmjenjenom prve odredbe o samostalnoj odgovornosti roditelja za počinjeni prekršaj kockanja mladjeg maloljetnika u noćnom periodu, u drugoj odredbi propisati zajedničku odgovornost, odnosno odgovornost roditelja uporedo sa starijim maloljetnikom za počinjeni prekršaj kockanja starijeg maloljetnika u noćnom periodu. U pogledu odredbe koja se odnosi na odgovornost roditelja za podsticanje maloljetnika na kockanje, koja je propisana u pojedinim zakonodavstvima, važno je utvrditi da su roditelj ili staratelj djelovali sa eventualnim umišljajem, koji mora obuhvatiti svijest da se utječe na maloljetnika - neposrednog izvršioca prekršaja kockanja i obilježja bića prekršaja koji će taj maloljetnik učiniti.

Također, u pogledu svih navedenih prekršajnih odredbi koje se odnose na prekršajno-pravnu zaštitu mladih od kockanja prisutne su razlike i u pogledu kaznene politike. Te razlike se ogledaju u velikoj nesrazmjeri između prekršajnih zakonodavstava u visini propisane novčane kazne $^{23}$ kako u pogledu odredbe za počinjeni prekršaj kockanja svih lica, uključujući i maloljetnika i radnje navođenja maloljetnika na kockanje, tako i u pogledu odredbe za počinjeni prekršaj kockanja maloljetnika uzrokovan roditeljskim nečinjenjem, odnosno propuštanjem njihovog dužnog nadzora nad odgojem maloljetnika ukoliko su takav nadzor bili u mogućnosti

23 U nekim zakonodavstvima znatno je pooštrenija kaznena politika u odnosu na ovu vrstu prekršaja. Tako je u prekršajnom zakonodavstvu Republike Srbije za ovu vrstu prekršaja protiv javnog reda i mira, odnosno za radnju kockanja ili drugu radnju kojom se maloljetnom licu omogućava kockanje, kao kvalifikatornu okolnost s obzirom na uzrast pasivnog subjekta, propisana isključivo zatvorska kazna od 30 do 60 dana, dok je za istu radnju u odnosu na punoljetna lica propisana novčana kazna, alternativno sa radom u javnom interesu od 120 do 360 časova (vid. čl.13. Zakona o javnom redu i miru Republike Srbije, Službeni Glasnik RS, br. 6/16 i 24/18). 
da vrše, ili pak uzrokovan njihovim podsticanjem na činjenje prekršaja kockanja mladih. Naime, u pogledu visine novčane kazne propisane za ovu prekršajnu inkriminaciju na nivou kantona u $\mathrm{FBiH}$, kao i u odnosu na prekršajno zakonodavstvo u entitetu $\mathrm{RS}$ i $\mathrm{BD} \mathrm{BiH}$, prisutna je velika nesrazmera, odnosno izrazito različita kaznena politika kako u pogledu neposrednog činjenja, odnosno kockanja i kažnjavanja za radnju omogućavanja ili navođenja maloljetnika na kockanje, tako i u pogledu odgovornosti roditelja za prekršaj maloljetnika uzrokovan roditeljskim nečinjenjem, odnosno propuštanjem dužnog nadzora nad odgojem maloljetnika ukoliko su taj odgoj bili u mogućnosti da vrše. Koliko je prisutna nesrazmjera, odnosno razlika u visini propisane kazne za ovu vrstu prekršaja, odnosno za radnju kockanja i navođenje maloljetnika na kockanje, pokazuje odredba po kojoj maksimum propisane novčane kazne u jednom kantonu (300 KM u ZDK) za ovu vrstu prekršaja je manji od minimuma propisane kazne u drugom kantonu (od 500 do $1000 \mathrm{KM} \mathrm{u} \mathrm{HNK}$ ), ili u RS (od 400 do $1000 \mathrm{KM}$ ) i BD BiH (od 500 do 1500 KM). ${ }^{24}$ Nesrazmjera, odnosno izrazita razlika u pogledu minimuma i maksimuma, odnosno visine propisane novčane kazne postoji i u pogledu prekršajne odredbe koja se odnosi na odgovornost roditelja za počinjeni prekršaj maloljetnika uzrokovan roditeljskim nečinjenjem. ${ }^{25} \mathrm{U}$ vezi navedenog neophodno je izvršiti izmene prekršajnih odredbi iz Zakona o javnom redu i miru u smislu usklađivanja odredbi o visini propisane novčane kazne za počinjene prekršaje kockanja prevashodno u onim kantonima u Federaciji $\mathrm{BiH}$ u kojima je propisan znatno manji minimum kao i maksimum propisane kazne sa odredbama iz Zakona o javnom redu i miru u kantonima sa većim minimumom i maksimumom propisane novčane kazne, kao i sa odredbama Zakona o javnom redu i miru entiteta RS i BD BiH. Ratio legis uvođenja ove izmene je što postojeća odredba o niskom minimalnom i maksimalnom iznosu novčane kazne u pojedinim kantonima (npr. ZDK) za počinjeni prekršaj pogoduje porastu recidivizma, kao i porastu primarnog prestupništva. Takva pojava je naročito izražena na medjuentitetskim i medjukantonalnim graničnim područjima gde se mogu češće vršiti ovi i drugi prekršaji jer je nizak iznos propisane novčane kazne za počinjeni prekršaj stimulativan kako za primarne počinioce prekršaja tako i za recidiviste, te se time povećava spremnost prekršioca propisa, odnosno prestupnika da preuzimaju rizik za prestupničko ponašanje (Orlić, Krštenić, Karović, 2019: 302).

Pored prekršajno-pravne zaštite maloljetnika od kockanja propisane odredbama Zakona o javnom redu i miru, ovaj oblik kazneno-pravne zaštite mladih od

24 Član 6. st.3. ZJRM ZDK, Službene novine ZDK, br.12/16, Član 5, st.4.tač.k. ZJRM HNK, Službene novine HNK, br.9/09, Član 13.st.1.ZJRM RS, Služneni Glasnik RS br.11/15, Član 15.st.1. ZJRM BD BiH, Službeni Glasnik BD BiH, br.14/10.

25 I u pogledu odredbe o prekršajnoj odgovornosti roditelja za počinjeni prekršaj (uključujući i kockanje) mlaoljetnika, uzrokovan, odnosno nastao usljed roditeljskog nečinjenja ili propuštanja dužnog nadzora nad odgojem maloljetnika ukoliko su bili u mogućnosti da takav nadzor vrše, prisutne je izrazita razlika u kaznenoj politici. Tako npr, maksimum propisane novčane kazne za ovaj prekršaj prema Zakonu o JRM ZDK (100-300 KM, čl.3.tač.25, Službene novine ZDK 12/16) je manji u odnosu na propisani minimum kazne prema Zakonu o JRM KS (400-1200 KM, ČL.8.st.4. tač. f, Službene novine KS, br. 18/07), te u odnosu na propisani minimum prema Zakonu o JRM entiteta RS (400-1200 KM, čl.27.st.2, Službeni Glasnik RS, br. 11/15), kao i u odnosu na propisani minimum prema Zakonu o JRM BD BiH (500-1500 KM, čl.34.st.3, Službeni Glasnik BD BiH, br. 14/10). 
kockanja propisuje se i odredbama Zakona o igrama na sreću kao lex specialis, koji sveobuhvatno reguliše igre na sreću u koje se ubrajaju i kockanje i klađenje. Prekršajno-pravna zaštita mladih od kockanja je regulisana odredbama Zakona o igrama na sreću kojim se propisuju zabrane i sankcije, odnosno novčane kazne za pravna i fizička lica po osnovu kršenja propisa po kojima maloljetnici, odnosno lica mlađa od 18 godina nemaju pravo na igru na sreću, tako da se maloljetnicima ne dozvoljava učestvovanje u igrama na sreću i zabranjuje pristup objektima u kojima se priređuju takve igre. ${ }^{26} \mathrm{U}$ cilju ostvarenja zabrane učešća maloljetnicima u igrama na sreću, u koje ubrajamo i kockanje i klađenje, u okviru istog člana propisana je i odredba o obavezi dokazivanja identiteta učesnika igara na sreću putem identifikacione isprave radi provere starosne dobi učesnika igara na sreću. Međutim, i pored propisanosti ove odredbe koja je nesumnjivo u funkciji sprečavanja ulaska mladih u svijet kockanja i klađenja i razvijanja potencijalne ovisnosti o istom, $\mathrm{u}$ praksi je evidentan problem provodivosti ove zakonske odredbe iz razloga što se ove provjere starosne dobi učesnika igara na sreću uopšte ne vrše ili ako se vrše ne postoji dosljednost i kontinuiranost u ovoj provjeri tako da danas imamo veliki broj mladih, uključujući i maloljetnike koji bez kontrole ulaze u objekte u kojima se priređuju igre na sreću i u istim učestvuju, što konsekventno tome dovodi do porasta učešča mladih u kockanju i klađenju sa tendencijom stvaranja ovisnosti o istom i opasnosti od činjenja kaznenih djela mladih uzrokovanih ovisnošću o kockanju. Pored zaštite mladih od kockanja putem propisivanja zabrane pristupa objektima u kojima se priređuju igre na sreću i zabrane učestvovanja u tim igrama, ova zaštita je regulisana i tako što je zakonodavac propisao obavezu za priređivača igara na sreću da na web stranici istakne, odnosno oglasi obavijest o zabrani učestvovanja maloljetnicima. ${ }^{27}$ Pored navedenog, u cilju zaštite mladih od kockanja ovim zakonom je propisana i zabrana objavljivanja oglasa i reklama vezanim za igre na sreću u radio i tv emisijama, te štampanom materijalu i internet portalima namjenjenim djeci i maloljetnicima. Drugim rječima, radi se o odredbi koja podrazumjeva tzv. obavezivanje medija da u odabranim programskim sadržajima prilagođenim mladjem uzrastu vode računa o izbjegavanju izlaganja mladjeg naraštaja neprimjerenim reklamnim i oglasnim sadržajima (kao što su i oglašavanja i reklamiranja igara na sreću) koji bi tendirali ka poticanju mladih na devijantna ponašanja u koje ubrajamo i kockanje. Medjutim, i pored propisanih zabrana, mladi naraštaji sa devijantnim obrascima ponašanja i bez odgovarajućeg roditeljskog nadzora uvijek traže način da učestvuju u raznim vidovima igara na sreću uključujući i klađenje, pri čemu je naročito aktuelno on line klađenje koje je veoma rašireno kako u Bosni i Hercegovini, tako i u zemljama regiona, pri čemu za takvo on line klađenje nije propisan zakonski okvir zašite mladih od ovog oblika ovisnosti, u smislu propisivanja prekršajne odredbe o inkriminirajućoj radnji omogućavanja, odnosno navođenja maloletnika

26 Član 62,85,88,97. (različitim članovima propisane iste zabrane u objektima - kladionice, kazina, objekti sa automati i poker aparatima itd, u kojima se priređuju različite igre na sreću) Zakona o igrama na sreću FBiH (Službene novine FBiH, br. 48/15 i 60/15), Član 12. Zakona o igrama na sreću RS (Službeni glasnik RS, br. 22/19) i član 19.st.1.Zakona o igrama na sreću BD BiH (Službeni glasnik BD BiH, br. 37/04 i 19/07).

27 Čl.111. Zakona o igrama na sreću FBiH. 
na on line klađenje. Ono je postalo socijalni problem sa obilježjima ovisnosti i dostupno je svima pa tako i mladima koji se razumiju u moderne tehnologije, te su u mogućnosti da, bez ograničenja, ispoljavaju takav oblik ovisnosti čemu naročito pogoduje nedovoljna supervizija roditelja u porodičnom domu, školi i van škole nad modernim tehnološkim aktivnostima djece (Orlić et al., 2019: 309).

Sa aspekta prestupničkog ponašanja mladih lica veliki problem predstavlja prerastanje kladionica i kockarnica u biznis kakav je slučaj u svim zemljama u tranziciji, gdje navodni biznismeni, ne birajući sredstva za zaradu, postavljaju kladionice i kockarnice tamo gdje im nije mjesto: pored škola, vjerskih objekata, mjesta gdje se mladi okupljaju i zabavljaju, te mjesta za rekreaciju, što predstavlja riziko faktor za pojavu prestupničkog ponašanja mladih (Nikolić, Joksić, 2011: 86). U cilju prekršajno-pravne zaštite mladih od izloženosti kockanju usljed blizine kladionica i objekata za u kojima se priređuju igre na sreću i škola i drugih odgojno obrazovnih ustanova, zakonodavac je propisao odredbu kojom je regulisana prostorna udaljenost kladionica i drugih objekata i prostora u kojima se priređuju igre na sreću na razmak od najmanje 100 metara od škola i drugih odgojno obrazovnih ustanova. ${ }^{28}$ Ono što je specifično za Bosnu i Hercegovinu je da i na primjeru ove odredbe, koja je veoma važna za zaštitu mladih od izloženosti kockanju i klađenju, dolazi do izražaja neujednačenost zakonske regulative iz razloga što ova odredba nije propisana u Zakonima o igrama na sreću u oba entiteta i Brčko distriktu BiH, tako da je ova odredba propisana samo u Zakonu o igrama na sreću entiteta Federacija $\mathrm{BiH},{ }^{29}$ a ne i u zakonodavstvu entiteta RS i Brčko distrikta $\mathrm{BiH}$. Danas je prisutan i problem velikog broja kladionica uz njihovu lociranost u večem broju na maloj udaljenosti u područjima sa većom frekvencijom građana. U cilju prevencije maloljetničkog kockanja i klađenja, pored zakonske propisanosti udaljenosti kladionica i drugih objekata u kojima se priređuju igre na sreću od škole i drugih odgojno-obrazovnih ustanova, potrebno je propisati i međusobnu udaljenost između kladionica i drugih objekata u kojima se priređuju igre na sreću od najmanje 100 metara.

Poseban oblik prekršajno-pravne zaštite mladih prema Zakonu o igrama na sreću se ostvaruje propisivanjem odredbe o odgovornosti roditelja po osnovu zaticanja mladjeg maloljetnika u učestvovanju u igrama na sreću, ${ }^{30}$ što podrazumjeva zaticanje u objektima u kojima se priređuju igre na sreću, kao i na uplatnim mjestima

28 I postojeća odredba o udaljenosti između kladionica i drugih objekata u kojima se priređuju igre na sreću od škola i drugih odgojno obrazovnih ustanova, propisana prema Zakonu o igrama na sreću $\mathrm{FBiH}$, nije najbolje rješenje, te smatramo da bi ta udaljenost u cilju prevencije maloljetničkog kockanja i klađenja trebala biti i veća. Kao primjer može poslužiti zakonodavstvo Republike Srbije gdje je prema Zakonu o igrama na sreću Republike Srbije propisana udaljenost između kladionica i škola od najmanje 200 metara, kao i međusobna udaljenost između kladionica i drugih objekata u kojima se priređuju igre na sreću od najmanje 100 metara (vid. Čl.67. Zakona o igrama na sreću Republike Srbije, Službeni glasnik RS, br.18/20).

$29 \check{C}$ l.48, 59, 89, 90 i 104 Zakona o igrama na sreću FBiH propisuje obavezu prostorne udaljenosti od najmanje 100 metara između objekata u kojima se priređuju igre na sreću i škola i vjerskih objekata.

30 Čl.132.st.3. Zakona o igrama na sreću FBiH. Ova odredba nije propisana u Zakonu o igrama na sreću RS i BDBiH. 
prilikom zaprimanja uplata. Odgovornost roditelja, u smislu ove prekršajne odredbe iz Zakona o igrama na sreću, temelji se na njihovom propustu da vrše nadzor nad maloljetnikom, pri čemu je zaticanje mladjeg maloljetnika u kockanju, kao obliku prestupničkog ponašanja, posljedica odgojne zapuštenosti tog maloljetnika od strane roditelja, tako da je učešče maloljetnika u kockanju rezultat neodgovornog i nemarnog odnosa roditelja prema maloljetniku, što je uzrok njegovog prestupničkog ponašanja. Ono što je specifično jeste da zakonodavac ovom odredbom odgovornost roditelja ograničava samo za učešče mladjeg maloljetnika u kockanju, pri čemu je izuzet iz odgovornosti po osnovu zaticanja starijeg maloljetnika u učešču u kockanju i drugim igrama na sreću, tako da u drugoj odredbi propisuje samu odgovornost starijeg maloljetnika za zaticanje u učešču u kockanju i drugim igrama na sreću. ${ }^{31}$ To znači da stariji maloljetnik, prema odredbama ovog zakona, sam snosi prekršajnu odgovornost za učešče u kockanju, dok je u odnosu na radnju učešća mladjeg maloljetnika u kockanju prekršajna odgovornost na samom roditelju, tako da se može reći da se mladjem maloljetniku pruža potpuna prekršajno-pravna zaštita od kockanja putem propisivanja odgovornosti za roditelja, dok se u slučaju starijeg maloljetnika ta zaštita ostvaruje putem propisivanja odredbe o njegovoj neposrednoj odgovornosti za počinjeni prekršaj. Smatramo da bi u pogledu ovih odredbi trebalo izvršiti izmjene koji bi mogle da se izvrše na jedan od dva prijedloga de le ge ferenda. Naime, prvi modalitet ili prijedlog rješenja izmjena bi podrazmumjevao da se propiše samno jedna odredba koja bi uključivala odgovornost roditelja po osnovu zaticanja maloljetnika u kockanju i drugim igrama na sreću što bi podrazumjevalo samostalnu odgovornost roditelja po osnovu zaticanja u igrama na sreću i mladjeg i starijeg maloljetnika. Drugi modalitet ili prijedlog rješenja izmjena bi bio da ostanu obje odredbe pri čemu bi u drugoj odredbi prekršajna odgovornost za radnju zaticanja u kockanju i drugim igrama na sreću uz starijeg maloljetnika bila proširena i na roditelja, tako da bi roditelja odgovorao za počinjeni prekršaj starijeg maloljetnika uporedo sa tim maloljetnikom. Shodno navedenom, prema prvom prijedlogu rješenja izmjena postojala bi samo jedna odredba u kojoj bi obe kategorije maloljetnika bile izuzete od odgovornosti po osnovu zaticanja u kockanju i igrama na sreću, tako da bi odgovornost snosio samo roditelj $\mathrm{i}$ ista bi se temeljila na njegovom propustu u vršenju dužnog nadzora nad maloljetnikom i njegovim odgojem. Prema drugom prijedlogu, postojale bi dvije odredbe uz izmjenu u drugoj odredbi koja bi umjesto samostalne odgovornosti starijeg maloljetnika za zaticanje u učešču u kockanju i drugim igrama na sreću podrazumjevala zajedničku odgovornost starijeg maloljetnika i roditelja, odnosno odgovornost roditelja uporedo sa starijim maloljetnikom. Druga propisana odredba po kojoj se roditelji izuzimaju od odgovornosti po osnovu zaticanja starijeg maloljetnika u učešču u kockanju i ostalim igrama na sreću je pogrešna. Osnovni argument za pogrešnost ove odredbe se temelji na tome da su roditelji i prema krivičnom zakonu dužni da vrše nadzor maloljetnika (i mladjih i starijih), odnosno nadzor nad njihovim odgojem i ponašanjem, te da za svaki propust u tom pogledu snose odgovornost, tako da niti u jednoj odredbi nema odvojenog tretiranja mladjih i

31 Čl. 132.st.4. Zakona o igrama na sreću FBiH. I ova odredba nije propisana u Zakonu o igrama na sreću RS i BD BiH. 
starijih maloljetnika u pogledu dužnosti roditelja da vrše dužni nadzor nad njihovim odgojem i ponašanjem. S tim u vezi jedinstvena je dužnost roditelja da vrše dužni nadzor nad odgojem maloljetnika, kako mladjih, tako i starijh, i prema odredbama krivičnog zakona, tako da nema izuzetaka u pogledu nepostojanja dužnosti roditelja da vrše dužni nadzor nad odgojem uzrasne, odnosno dobne kategorije starijih maloljetnika i u drugoj oblasti kaznenog zakonodavstva, odnosno u prekršajnom zakonodavstvu.

Pored neophodnosti izmjene navedenih odredbi, prisutan je i problem provodivosti postojećih odredbi. Naime, i pored propisanosti ovih odredbi koje su s jedne strane usmjerene na podizanje većeg stepena odgovornosti roditelja u vršenju dužnog nadzora nad maloljetnikom i njegovim odgojem i ponašanjem, te s druge strane na sprečavanje ulaska mladih u svijet kockanja i klađenja i razvijanja potencijalne ovisnosti o istom, u praksi je evidentan problem provodivosti ove zakonske odredbe iz razloga što se provjere starosne dobi učesnika igara na sreću, bilo od strane priređivača igara na sreću i zaposlenog osoblja u objektima u kojima se priređuju igre na sreću, bilo od strane inspekcije u okviru njihovog nadzora, uopšte ne vrše ili ako se vrše ne postoji dosljednost i kontinuiranost u ovoj provjeri tako da danas imamo veliki broj mladih, uključujući i maloljetnike koji zbog propusta roditelja u vršenju nadzora nad njima i njihovim odgojem i ponašanjem, bez kontrole ulaze u objekte u kojima se priređuju igre na sreću i u istim učestvuju, što konsekventno tome dovodi do porasta učešča mladih u kockanju i klađenju sa tendencijom stvaranja ovisnosti o istom i opasnosti od činjenja kaznenih djela mladih uzrokovanih ovisnošću o kockanju.

Pored navedenog, prema odredbama ovog zakona je prisutna i razlika u kaznenoj politici, odnosno u visini propisane novčane kazne u entitetskim i distriktnom zakonodavstvu po osnovu zaticanja maloljetnika u objektima u kojima se priređuju igre na sreću. ${ }^{32} \mathrm{~S}$ tim u vezi, i u ovom zakonodavstvu je potrebno ujednačiti kaznenu politiku, odnosno minimum i maksimum propisane novčane kazne, tako da bude propisan jednak iznos novčane kazne u svim zakonodavstvima za počinjeni prekršaj učešča u kockanju i drugim igrama na sreću.

Rezime rada: Mladi kao najosjetljivija kategorija društva su danas izloženi brojnim devijantnim pojavama, pri čemu su naročito izloženi uticaju brojnih ovisnosti od kojih se danas naročito izdvaja kockanje koje svojom masovnošču kod mladih postaje glavni izvor ovisnosti mladih i uzročnik ulaska mladih u svijet prestupništva. Pored preduzimanja brojnih preventivnih mjera usmjerenih na suzbijanju pojave kockanja kod mladih u kojima osnovni nosioci prevencije trebaju biti porodica i odgojno obrazovne ustanove, poseban akcenat se daje i na legislativnim, odnosno kazneno-pravnim aspektima zaštite mladih od kockanja. Ovi aspekti zaštite mladih

32 Propisana kazna za pravna lica prema čl.129.tač.12. Zakona o igrama na sreću je od 5.000 do $12.000 \mathrm{KM}$, što je u odnosu na zakonodavstvo u RS (20.000 - 50.000 KM prema čl.114) i BD BiH (2.000$50.000 \mathrm{KM}$ prema članu 76) znatno manje. Razlika u visini, odnosno minimumu i maksimumu propisane novčane kazne je toliko izražena da je maksimum propisane novčane kazne u FBiH (12.000 KM) znatno manji od minimuma propisane novčane kazne u RS (20.000 KM). 
od kockanja se javljaju u više oblika sa više modaliteta propisanih odredbi kojima se mladima pruža kazneno-pravna zaštita od ovog oblika asocijalnog ponašanja. Kazneno-pravna zaštita mladih od kockanja u Bosni i Hercegovini se ostvaruje putem krivično-pravne regultative prema odredbama krivičnog zakona i putem prekršajno-pravne regulative prema odredbama Zakona o javnom redu i miru i odredbama Zakona o igrama na sreću kao lex spacialis. U pogledu kaznenopravne zaštite mladih od kockanja u Bosni i Hercegovini evidentno je da postojeća zakonska rješenja u krivičnom i prekršajnom zakonodavstvu su dosta manjkava i neujednačena, te kao takva ne pružaju adekvatan okvir zaštite mladih od kockanja. S tim u vezi, u cilju efikasnije kazneno-pravne zaštite mladih od kockanja, u pogledu krivično-pravne i prekršajno-pravne regulative, potrebne su sljedeće izmjene:

- U cilju postizanja bolje i cjelovitije, te jače krivičnopravne zaštite mladih lica od kockanja, priedlog de lege ferenda je da se u okviru izmjena u našem krivičnom zakonodavstvu izvrši inkriminalizacija kockanja i u krivično zakonodavstvo FBiH i BD BiH kako bi se maloljetnicima pružila cjelovitija, odnosno krivično pravna zaštita na cijelom teritoriju $\mathrm{BiH}$, te da se u postojećoj inkriminaciji „kockanje“ u krivičnom zakonodavstvu Republike Srpske, uz uvođenje takve inkriminacije i u krivičnom zakonodavstvu $\mathrm{FBiH}$ i $\mathrm{BD} \mathrm{BiH}$, propise odredba o kažnjavanju lica za radnju navođenja djeteta, odnosno maloljetnika na kockanje koja bi predstavljala kvalifikatornu okolnost s obzirom na starosnu dob pasivnog subjekta i teži oblik djela, čime bi se pružila potpunija krivično-pravna zaštita djece, odnosno maloljetnika od ovog vida sociopatološkog ponašanja.

- Takođe, u okviru izmjena u krivičnom zakonodavstvu koje se odnose na kockanje mladih, potrebno je da se ujednači visina kazne, odnosno propiše jednak posebni minimum i maksimum kazne unutar opšteg kaznenog okvira za kvalifikatornu okolnost kod krivičnog djela „Zapuštanje ili zlostavljanje djeteta ili maloljetnika" koja se odnosi na odavanje asocijalnom ponašanju, odnosno kockanju, na način da se i u krivičnom zakonodavstvu FBiH i BD BiH propiše viši posebni minimum i maksimum kazne zatvora, odnosno da bude isti kao u KZ RS i iznosi od 1 do 8 godina, kako bi se time mladim licima pružila jača krivično-pravna zaštita od kockanja i drugih oblika asocijalnog ponašanja uzrokovanog radnjama grubog zanemarivanja odgoja djeteta ili maloljetnika iz stava 1.člana $219 \mathrm{KZ} \mathrm{FBiH} \mathrm{i} \mathrm{opciono} \mathrm{propisanim} \mathrm{kvalifikatornim} \mathrm{radnjama}$ iz stava 2 istog člana, počinjenim od strane roditelja, usvojitelja, staratelja ili drugog lica.

- U okviru prekršajno-pravne zaštite mladih od kockanja prema odredbama Zakona o javnom redu i miru potrebno je ujednačiti legislativu i u pogledu odredbi koje se odnose na odgovornost roditelja za počinjeni prekršaj maloljetnika, uzrokovan roditeljskim nečinjenjem, u noćnom i drugom periodu, na jedan od dva načina. Prema prvom prijedlogu rješenja, potrebno je da se u svim, a ne samo u nekim, prekršajnim zakonodavstvima propiše odgovornost roditelja za počinjeni prekršaj kockanja maloljetnika (i mlađih i 
starijih) i u noćnom i u drugom periodu, uzrokovan roditeljskim nečinjenjem, uz propisanost većeg iznosa novčane kazne za roditelje po osnovu počinjenog prekršaja kockanja maloljetnika u noćnom periodu, imajući u vidu vrijeme počinjenja navedenog prekršaja i veći stepen propusta roditelja u pogledu nadzora nad ponašanjem, odnosno odgojem maloljetnika. Prema drugom prijedlogu rješenja, potrebno je da se uz neizmjenjenu odredbu o samostalnoj odgovornosti roditelja za počinjeni prekršaj kockanja mladjeg maloljetnika u noćnom periodu, propiše odredba o zajedničkoj odgovornosti, odnosno odgovornosti roditelja uporedo sa starijim maloljetnikom za počinjeni prekršaj kockanja starijeg maloljetnika u noćnom periodu.

- Zbog velike nesrazmjere između prekršajnih zakonodavstava u visini propisane novčane kazne, kako u pogledu odredbe za počinjeni prekršaj kockanja svih lica, uključujući i maloljetnika i radnje navođenja maloljetnika na kockanje, tako i u pogledu odredbe za počinjeni prekršaj kockanja maloljetnika uzrokovan roditeljskim nečinjenjem, odnosno propuštanjem njihovog dužnog nadzora nad odgojem maloljetnika ukoliko su takav nadzor bili u mogućnosti da vrše, ili pak uzrokovan njihovim podsticanjem na činjenje prekršaja kockanja mladih, neophodno je izvršiti izmene prekršajnih odredbi iz Zakona o javnom redu i miru u smislu usklađivanja odredbi o visini propisane novčane kazne za počinjene prekršaje kockanja prevashodno u onim kantonima u Federaciji $\mathrm{BiH}$ u kojima je propisan znatno manji minimum kao i maksimum propisane kazne sa odredbama iz Zakona o javnom redu i miru u kantonima sa većim minimumom i maksimumom propisane novčane kazne, kao i sa odredbama Zakona o javnom redu i miru entiteta RS i BD BiH

- Kada je u pitanju prekršajno-pravna zaštita mladih od kockanja prema odredbama Zakona o igrama na sreću kao lex specialis potrebne su izmjene zakonske regulative u pogledu propisane odredbe o odgovornosti roditelja po osnovu učešča maloljetnika u kockanju i drugim igrama na sreću. U pogledu ove odredbe izmjene bi trebale ići ili u pravcu propisivanja prekršajne odredbe o samostalnoj odgovornosti roditelja po osnovu zaticanja i mladjih i starijih maloljetnika u učešču u kockanju i drugim igrama na sreću, ili pak u pravcu propisivanja, uz samostalnu odgovornost roditelja po osnovu učešča mladjeg maloljetnika u kockanju, i zajedničke odgovornosti roditelja po osnovu zaticanja starijeg maloljetnika u kockanju, odnosno odgovornosti roditelja uporedo sa starijim maloljetnikom.

- U okviru prekršajno-pravne regulative koja se odnosi na kockanje mladih prema odredbama ovog zakona, u cilju prekršajno-pravne zaštite mladih od izloženosti kockanju usljed postojanja kladionica i drugih objekata u kojima se priređuju igre na sreću u blizini škola i drugih odgojno obrazovnih ustanova, kao i međusobne blizine, odnosno postojanja većeg broja takvih objekata na maloj udaljenosti jednih od drugih, potrebno je ujednačiti zakonsku regulativu, te u svim zakonodavstvima propisati odredbu kojom je regulisana prostorna udaljenost kladionica i drugih objekata i prostora u kojima se priređuju igre na 
sreću na razmak od najmanje 100 metara od škola i drugih odgojno obrazovnih ustanova, kao i međusobna udaljenost između kladionica i drugih objekata u kojima se priređuju igre na sreću na istoj udaljenosti od najmanje 100 metara.

- Takođe, zbog propisane različite kaznene politike i prema odredbama ovog zakona kao lex specialis, potrebno je u entiteskom i distriktnom zakonodavstvu ujednačiti kaznenu politiku, odnosno minimum i maksimum propisane novčane kazne, tako da bude propisan jednak iznos novčane kazne u svim zakonodavstvima za počinjeni prekršaj učešća u kockanju i drugim igrama na sreću.

\section{LITERATURA}

1. Babić, M, Marković, I. (2018). Krivično pravo - posebni dio, Banja Luka: Pravni fakultet Banja Luka;

2. Karić, N. (2017) Socijalni rad i maloletnička delinkvencija u zajednici, Tuzla: OFFSET;

3. Klarić, D. (2014). Prepoznaj i djeluj: Savjetnik za prevenciju ovisnosti i nasilja u djece i mladih, Zagreb: Školska knjiga;

4. Milosavljević, M. (1986). Socijalna patologija, I izdanje, 'Svetlost' Sarajevo;

5. Milutinović, M. (1979) Kriminologija, Beograd: Savremena administracija;

6. Mirić, A. F. (2014). Savremena shvatanja etiologije i fenomenologije maloletničke delinkvencije, doktorska disertacija, Niš: Pravni fakultet Niš;

7. Mladenović, I. i Lažetić, G. (2018). Zavisnost od kockanja, Beograd: Čigoja;

8. Munjiza, M. (2017). Psihopatologija svakodnevnog života,Vodič za zdrave i bolesne, za roditelje i njihovu decu, Treće izdanje, Beograd: Službeni Glasnik;

9. Nikolić, Z. (2006). Prevencija kriminaliteta, Metodika rada savjetovališta za roditelje i djecu, Beograd: Institut za kriminološka i sociološka istraživanja;

10. Nikolić, Z. i Joksić, I. (2011). Maloletnička delinkvencija - socijalnopsihološki i krivičnopravni aspekti. Beograd: Institut za kriminološka i sociološka istraživanja;

11. Orlić, S, Pehlić, I i Tufekčić, N. (2019). Maloletničko prestupništvo, Zenica: IPF;

12. Orlić, S, Krštenić, J i Karović, S. (2019). Sociopatološke zavisnoati i legislativni okviri zaštite mladih u Bosni i Hercegovini sa osvrtom na stanje u Srbiji - De lege lata et de lege ferenda, Beograd: Pravni život, br. 9/19;

13. Skakavac, Z, T. (2014). Recidivizam maloletnih učinilaca krivičnih dela, doktorska disertacija, Niš: Pravni fakultet;

14. Šarić, H. (2008). Prostitucija i ostali oblici socijalne patologije, Tuzla: OFF.SET;

15. Špadijer-Džinić, J. (1988). Socijalna patologija (sociologija devijantnosti), Beograd: Zavod za udžbenike i nastavna sredstva;

16. Tomić, Z. (2007a). Krivično pravo - krivično djelo, Sarajevo: Pravni fakultet Sarajevo;

17. Tomić, Z. (2007b). Krivično pravo - posebni dio, Sarajevo: Pravni fakultet Sarajevo;

18. Tukar, M. (2018). Komentar Zakona o javnom redu i miru, drugo dopunjeno izdanje, Beograd: Službeni glasnik; 


\section{Propisi}

1. Krivični zakon Federacije Bosne i Hercegovine (Službene novine FBiH br.75/17)

2. Krivični zakon Republike Srpske (Službeni glasnik RS, br. 64/17, 104/18. odluka US)

3. Krivični zakon Brčko distrikta Bosne i Hercegovine (Službeni glasnik BD BiH, br. $50 / 18)$

4. Zakon o javnom redu i miru Republike Srpske (Službeni glasnik RS, br. 11/15)

5. Zakon o javnom redu i miru Brčko distrikta Bosne i Hercegovine (Službeni glasnik BD BiH, br. 14/10)

6. Zakon o javnom redu i miru Zeničko-dobojskog kantona (SN ZDK, br. 12/16)

7. Zakon o javnom redu i miru Kantona Sarajevo (Službene novine KS, br. 18/07)

8. Zakon o javnom redu i miru Srednjo-bosanskog kantona (Službene novine SBK, br. $05 / 10)$

9. Zakon o javnom redu i miru Hercegovačko-neretvanskog kantona (Službene novine HNK, br. 09/09);

10. Zakon o javnom redu i miru Republike Srbije (Službeni Glasnik RS, br. 6/16 i 24/18);

11. Zakon o igrama na sreću FBiH (Službene novine FBiH, br.48/15 i 60/15);

12. Zakon o igrama na sreću Republike Srpske (Službeni glasnik RS, br. 22/19);

13. Zakon o igrama na sreću Brčko distrikta Bosne i Hercegovine (Službeni glasnik BD $\mathrm{BiH}$, br. 19/07)

14. Zakon o igrama na sreću Republike Srbije (Službeni glasnik Republike Srbije, br.18/20).

\section{GAMBLING AND CRIMINAL PROTECTION OF YOUNGSTERS IN BOSNIA AND HERZEGOVINA}

Gambling as a social deviation is becomig an increrasingly topical issue in today!s world of consumerism and disturbed social values. As a social deviation, its mass threatens to grow into a leading addiction which would lead to various forms of punishable behavior. Such a threat is specially pronounced for the younger generation who can easily become addicted to this deviation and consequently be exposed to various forms of criminal behavior. In this paper, authors elaborated the criminal law protection of young people from gambling with a complete interpretation of all its forms and pointed our certainshortcomings in the legislative aspects of this protectionand the inconsistency of our legislation related to this form of anti-social behavior of young people, as well as problem in the effectiveness of the implementation of legal provisions that treat the protection of young people from gambling, with the presentation of appropriate proposals de lege ferenda aimed at improving the criminal law protection of young people in all its forms and modalities.

Key words: criminal law protection, misdemeanor law protection, gambling, addiction 